Article

\title{
Are Arid Regions Always that Appropriate for Waste Disposal? Examples of Complexity from Yucca Mountain, Nevada
}

\author{
Scott W. Tyler \\ Department of Geological Sciences and Engineering, University of Nevada, Reno, NV 89557, USA; \\ styler@unr.edu
}

Received: 2 December 2019; Accepted: 10 January 2020; Published: 14 January 2020

\begin{abstract}
The study of the hydrology of arid regions greatly expanded at the end of the 20th century as humans sought to reduce groundwater pollution from landfills, waste dumps and other forms of land disposal. Historically viewed as wastelands where little or no water percolated to the underlying water table, the discovery of large-scale contamination beneath arid disposal sites such as the Hanford nuclear complex in eastern Washington jumpstarted an industry in studying the hydrology of arid vadose zones and their transport behavior. These studies showed that, in spite of hyper aridity in many areas, precipitation often did infiltrate to deep water. The efforts at Yucca Mountain, Nevada to design a high-level nuclear repository stand out as one of the largest of such studies, and one that fundamentally changed our understanding of not only water flow in fractured rocks, but also of the range of our uncertainty of hydrologic processes in arid regions. In this review and commentary, we present some of the initial concepts of flow at Yucca Mountain, and the evolution in research to quantify the concepts. In light of continued stockpiling of high-level waste, and the renewed interest in opening Yucca Mountain for high-level waste, we then focus on the significant surprises and unanswered questions that remained after the end of the characterization and licensing period; questions that continue to demonstrate the challenges of a geologic repository and our uncertainty about critical processes for long-term, safe storage or disposal of some of our most toxic waste products.
\end{abstract}

Keywords: arid hydrology; nuclear waste; Yucca Mountain

\section{Introduction}

The use of arid regions for the disposal of waste is not a new concept; the lack of water, people, agriculture wildlife and general "wasteland" concept of many desert regions suggested that these areas could serve little other purposes. However, when water is available, for example along the Nile or Euphrates Rivers, agriculture and wildlife have prospered for millennia. In the last century, with the development of the field of groundwater hydrology and the ability to pump large quantities groundwater, many arid and semiarid (here we define semi-arid as less than $\sim 300 \mathrm{~mm}$ per year of precipitation, arid as $<150 \mathrm{~mm}$ per year and both possessing a high evaporative demand) regions have become highly productive in terms of agriculture.

But, away from water, arid regions were generally thought to be "hydrologically" inactive. Limited infiltration suggested that the potential for isolation of toxic wastes would be possible. The leaking of toxic and radioactive waste at more humid disposal facilities, such as at Love Canal and the West Valley nuclear fuel reprocessing facility in upstate New York, focused attention on hydrologic issues related to landfills and contaminant transport in both the saturated and unsaturated zones. In the US, nuclear weapons production and testing had already begun to use arid regions for waste disposal, 
such as at Hanford Washington and the Nevada Test Site (now known as the Nevada National Security Site or NNSS), based on the notion that the hydrologic conditions, i.e., the much greater potential evaporation than precipitation, of the arid climate would not allow the wastes to move to groundwater. Disposal at these sites was also convenient, as the waste was produced locally and did not need to be transported very far.

The parallel development of industry-produced toxic wastes and the knowledge of soils and groundwater hydrology associated with the expansion of arid region agriculture led, in large part, to the rapid growth of the field of "vadose zone hydrology" in the 1970s and 1980s. Prior to this time, the fields of soil physics and groundwater hydrology had evolved largely independently, driven by their separate foci on the near-surface soils related to agronomy and the deep recharge of aquifers related to hydrogeology. The need for the understanding of contaminant transport throughout the unsaturated zones from the land surface to the water tables of arid and semi-arid regions was driven by increased regulatory requirements for waste disposal as well as the recognition that agricultural development in arid regions meant that water was now available to potentially transport nutrients, pesticide, herbicides and any other constituents to the groundwater water, which in many cases was supplying the water used for agriculture.

As vadose zone hydrology matured, it became increasingly obvious that arid regions were not hydrologically "dead", but rather there were complex interactions between soils, geology, precipitation and vegetation that strongly controlled the movement (or lack thereof) of infiltration and groundwater recharge. As summarized by Reith and Thomson [1], the concept of "deserts as dumps" had chosen to ignore these complexities and data gaps in the decision-making process. Observations of groundwater contamination at Hanford Washington from disposal well above the water table were initially surprising, yet lysimeter studies quickly showed that disruption and removal of vegetation (a standard practice at most arid region waste sites) led to much-enhanced groundwater recharge (see, for example, Gee et al. [2]). These results were confirmed numerous times under very different conditions and environments, and showed that deep infiltration and recharge could easily occur in arid regions in spite of the lack of precipitation (see, for example, Scanlon et al. [3]) and the numerous references cited within).

In this century, it is well recognized that the hydrology of arid regions is complex and challenging. It has only been in the last 50 years that a clear understanding and modeling of the role of spatial variability of hydraulic properties in controlling infiltration and contaminant transport has arisen. Processes such as preferential flow, the exchange between mobile and less mobile pore waters, unstable wetting front behavior and vapor transport are now routinely considered in modeling the transport behavior in the vadose zone. This recognition of the complexity generally has been methodically evolving with each new study, but can be quite dynamic, as was discovered in 2015 when a closed, low-level radioactive landfill near Beatty Nevada suddenly exploded after several days of heavy precipitation. Infiltration through the unvegetated (and unlined) cover reacted with buried elemental sodium to produce several large explosions and surface contamination. The sodium had been buried in oil-filled drums decades previously, and because of the arid climate, it was thought that the drums would be secure indefinitely. As we now know, water is ubiquitous in the vadose zone and corrosion did occur, leaving the sodium high and dry and waiting for an infiltration event.

This is one example of an awakening to the complexity of the vadose zone and its behavior. We now turn our attention to Yucca Mountain, Nevada, where complexity in the unsaturated zone and its implication for nuclear waste isolation continues today.

\section{Enter Yucca Mountain: History and Status}

The United States, as well as many other nuclear nations, has generally followed a path for nuclear waste that relies upon geologic disposal to isolate the waste from humans and the environment. Beginning in the 1950s, the US National Academy of Sciences reviewed the use of salt deposits for the ultimate disposal of both commercial nuclear fuel as well as long-lived and highly radioactive 
waste from nuclear weapons production [4]. Through the latter half of the 20th century, deep geologic disposal became the preferred alternative for highly radioactive spent nuclear fuel from commercial power reactors. Through a long and often political process, Yucca Mountain in southern Nevada was chosen to be the US's first nuclear repository (for a more complete history and summary of scientific work of the Yucca Mountain process, the reader is referred to the excellent summaries of Cotton [5]; Stuckless [6] and Stuckless and Levich [7]) and the references therein.

The Yucca Mountain site is located in southern Nevada, on the far western boundary of the Nevada National Security Site. At first glance, Yucca Mountain demonstrated several positive characteristics for deep geologic disposal. The site was arid, with an average annual precipitation of $\sim 165 \mathrm{~mm} / \mathrm{year}$ [8]. The geology was also favorable, as the rocks were volcanic in origin with low primary porosity and in places contained significantly zeolite minerals capable of sorbing many dissolved radionuclides. The fact that the proposed repository rock was well above $(\sim 300 \mathrm{~m})$ the water table was considered to be positive from a water transport perspective, but negative from radionuclide solubility perspective, as the oxidizing environment would promote corrosion and solubility of uranium and several long-lived radionuclides [9].

Interestingly, many of these same geologic and hydrologic characteristics can be found across much of the DOE-controlled lands, yet only Yucca Mountain was seriously investigated. At the time of initial site selection, much of the NNSS was either used for testing of nuclear weapons, was proposed for testing, or had been too contaminated for significant surface activities. Yucca Mountain was "allowed" to be investigated because it was not planned for any future weapons testing [6]. Therefore, from the start, the site was not chosen for its significant potential for safe waste disposal, but rather its waste disposal potential would have to be "fit" into whatever was discovered beneath Yucca Mountain.

Characterizing Yucca Mountain for its suitability for long-term disposal of nuclear waste began in earnest in 1980 with the first set of boreholes to evaluate hydrology and geology. The first borehole designed specifically to assess the unsaturated zone hydrology (UZ-1) was completed in 1983 [10,11]. Site characterization of all aspects of the suitability continued through the 1990s and into the 2000s. By 2002, the US Congress voted to develop Yucca Mountain as the nation's first deep geologic repository for high-level radioactive waste. After significant delays and controversies, the DOE submitted a license application to the Nuclear Regulatory Commission (NRC) in 2008 [12]. After even more delays and controversies, the NRC completed its final supplemental Environmental Impact Statement in May 2016. The final adjudicatory hearing, required before any licensing decision can be made, is still suspended at the time of this writing, however.

The conceptual models of fluid flow, radionuclide transport and geologic stability of Yucca Mountain have evolved significantly over time as site characterization revealed greater and greater complexities [13]. As clearly summarized by Macfarlane and Ewing [12], while deep geologic repositories may offer the best solution for nuclear waste management, a continuous focus must be kept on understanding and reducing the uncertainties in such a complex geologic system.

Facing head-on the uncertainties and discoveries of new processes that will impact waste mobility with technically sound science is required to build and maintain public trust in the effort. Rechard et al. [14] provide an excellent analysis of "lessons learned" from the characterization efforts at both Yucca Mountain and from the Waste Isolation Pilot Program (WIPP). Rechard et al. [14] recognize the importance of the concept of "reasonable expectation", where not only is regulatory compliance required, but also a demonstration of fundamental understanding of the processes responsible for waste isolation. The public and those responsible for public safety will not allow potential flaws or significant gaps in the understanding of observed processes to be swept under the rug and, as a result, litigation and public protest is likely to draw out the process for decades, as has been the case for many environmentally sensitive projects such as large dams, pipelines and nuclear power projects.

The sections below highlight three hydrologic uncertainties and controversies that remain today, in spite of almost 40 years of research and significant expenditure. The hydrologic uncertainties are not alone, as other significant uncertainties exist in the geologic process, tectonic and seismic 
processes, as well as the metallurgical/corrosion processes that will occur over the $\sim$ million-year life of the repository [12]. It is this author's opinion that most of these issues need to be addressed to a much greater degree than has been done to date in order to gain the scientific and public trust necessary to invest significant quantities of public and rate-payer funds.

\section{Examples of Uncertainties, Data Gaps and Evolution of Knowledge}

\subsection{The Ever-Increasing Rate of Deep Infiltration and Recharge}

At first glance, the aridity of the region, the depth to groundwater and the relatively low matrix permeability of some of the volcanic tuffs in the unsaturated zone would suggest that deep infiltration and groundwater recharge would be very small at Yucca Mountain. The first estimations of recharge, based on thermal measurements, actually suggested an annual net upward flux from the water table of perhaps 1-2 mm [15]. Weeks and Wilson [16] initially estimated annual fluxes of between 0.003 and $0.02 \mathrm{~mm}$ as downward flux. Summarizing likely recharge rates, Montazar and Wilson [15] suggested recharge could range from essentially zero to up to $4.5 \mathrm{~mm}$ per year, settling the best estimate of $0.5 \mathrm{~mm}$ per year and assuming that the recharge was traveling through the rock matrix, rather than fractures.

Observations of perched water within the unsaturated zone of ages younger than could be supported by these small rates of recharge $[17,18]$ and infiltration studies began a slow but steady increase in the estimated recharge rate at Yucca Mountain [19]. Flint et al. [20] modeled area averaged annual recharge rates of between 5 and $10 \mathrm{~mm}$, with chloride mass balance estimates as high as $\sim 15 \mathrm{~mm}$ per year. At these rates, the average annual recharge is approaching $10 \%$ of the average annual precipitation over the site, and not inconsistent with other arid regions dominated by thin soils [3]. However, some localized areas (where soils were thin and where runoff could occur) could achieve model recharge rates as high $250 \mathrm{~mm}$ per year.

Modeling for future climates pushes this recharge rate up even higher as the current interglacial conditions generate less precipitation and greater evaporation than that estimated for past and future glacial periods. Stofhoff et al. [21] estimated area-averaged recharge rates of up to $41 \mathrm{~mm}$ per year accounting for both glacial and interglacial conditions.

By the mid 1990s, it was recognized that the very low matrix permeability of the repository horizon tuff could not support downward fluxes and that a significant portion of the recharge, if occurring, traveled through fractures during some portion of its traverse to the water table [20]. Flow through fractures in the unsaturated zone results in much shorter travel times from the land surface to the water table, and has now been documented in many fracture environments as the dominant transport path (see, for example, Nativ et al. [22]; Stauffer and Stone [23]).

Fracture flow and rapid transport potential were counters to the original conceptual design of the Yucca Mountain and generated significant research and modeling to understand its implications. The most controversial observation was first reported in 1997, with the measurement of young (<50-year-old) water in the repository horizon rock [24]. Fabryka-Martin et al. [24] observed chlorine-36 concentrations in seeps and faults exposed during tunneling operations at Yucca Mountain in the Topopah Springs Tuff indicative of waters that came from the surface ( $400 \mathrm{~m}$ above the sample depths) after nuclear weapons testing began in the 1940s. This observation generated significant debate and skepticism leading to a resampling by the U.S. Geologic and the University of Nevada, Las Vegas. Such fast transport called into question the suitability of the repository to many observers, as the concept of a deep and isolated geologic repository appeared to be no longer be the case.

From 1997 through 2006, teams at Los Alamos National Laboratory, the USGS and University of Nevada, Las Vegas analyzed and reanalyzed new and old samples to determine "who was right". The studies ended in 2006, not because of a resolution, but rather because of the end of funding for analysis [25]. Campbell et al. [26] present their case for the validity of the observations; the USGS reports: "The validation study work conducted by USGS-LLNL did not confirm previously reported bomb-pulse $36 \mathrm{Cl} / \mathrm{Cl}$ ratios in the Sundance fault zone, but new analyses at LANL of Niche \#1 core 
samples and ECRB Cross Drift tunnel-wall samples were consistent with results". Finally, UNLV reports challenges with analysis overall. As of this writing, one of the most potentially "game-changing" results for the hydrologic behavior of the repository remains in the "uncertainty" pile of results. This is not to say the scientific results are incorrect, but rather that the public and regulators only see further uncertainty rather than a reduction in uncertainty that would normally occur after further study. The uncertainty clouds the debate, as one can cast doubt by inference. For example, Stuckless and Levich [6] state on the issue of Cl-36 in the unsaturated zone: "later work by LLNL, the USGS and the University of Nevada, Las Vegas failed to confirm the widespread existence of these fast pathways". Such a statement could also easily be rewritten, with completely different implications, that: "later work by LLNL, the USGS and the University of Nevada, Las Vegas confirmed the existence of fast pathways". Both statements are correct, but neither reduces the uncertainty or reaches a conclusion based on sufficient study of the impacts on the hydrologic conceptual model.

In spite of the failure to reduce uncertainty, fast pathways for water infiltration were included in most models used to characterize the site, albeit with limited field observational data as the site characterization phase was winding down as the chlorine-36 was being discovered (for example, Bodvarsson et al. [27]). How well these models simulate the actual fluid fluxes and velocities at Yucca Mountain also remains in the uncertainty "pile" as site characterization has long ended.

\subsection{Whose Infiltration Model is Right?}

As the predicted recharge rate was increasing in the 1990s from nearly zero to something that was visible to the naked eye (at least a few millimeters per year), it became feasible and scientifically justifiable to develop and apply models across the soil surface to predict infiltration, runoff, evapotranspiration and deep recharge. These types of models have been widely applied to humid regions, and while possessing significantly more uncertainty in arid regions (where evapotranspiration dominates the water budget), can serve to better understand the partitioning of water into deep infiltration. These models are dependent upon characterization of the soil, vegetation and knowledge of the climatic conditions.

At Yucca Mountain, a significant data collection effort was undertaken to assess the near-surface hydrology and climate conditions (see, for example, Flint et al. [13]) and to develop the data sets that are needed to drive these water budget models.

During the modeling phase of data analysis in 2005, issues with lack of compliance with data quality assurance (QA) were raised that led to the Department of Energy abandoning the USGS infiltration modeling effort and launching a new modeling effort by Sandia National Laboratory to estimate infiltration across the Yucca Mountain area. This new modeling effort (termed MASSIF), while retaining much of the conceptual processes and modeling concepts as the preceding USGS model (termed INFIL), did not include all site-specific data, specifically parameters that are critical drivers of infiltration such as soil depth and soil hydraulic properties [28]. For example, soil hydraulic properties in the MASSIF simulations were based on data collected at the Hanford Nuclear Reservation in eastern Washington, a completely different geologic setting and $\sim 2000 \mathrm{~km}$ away. The resulting model of infiltration generally produced higher rates of infiltration than that of previous models. A complex parameter estimation and fitting algorithm was applied to generate results that were more in line with previous estimates [29]. The results of the MASSIF simulations were subsequently used in the Yucca Mountain license application. The reader is referred to [30,31] for a complete description of these two modeling efforts.

The lack of site-specific data in the model and the resulting statistical refitting was criticized by internal DOE reviews of the work, stating that the work did not provide a "technically credible spatial representation of the net infiltration at Yucca Mountain" [29]. The Nuclear Waste Technical Review Board found that while the modeling approaches were scientifically sound, they too question the final results, stating: "As used by DOE, the statistical modification of the infiltration estimates does not have a strong technical basis". 
In each of these reviews, the requirement to ignore existing field hydrologic and soils data were the basis of the reviewers' concerns, with only minor questions and clarifications cited on the conceptual modeling or modeling effort. For example, soil depth (or depth to bedrock) represents one of the most important factors in controlling deep infiltration in many arid regions, yet very few actual measurements of soil thickness were used in these models, which relied upon a statistical representation of the distribution of soil thickness. Soil depth was not a difficult parameter to measure in the field at the time, and improvements in ground penetrating radar today make the measurement even simpler. However, because of the quality assurance questions, most of the available data were not included.

These modeling efforts used for the licensing application were conducted 15-20 years ago and utilized a simple water budget concept that has proven quite appropriate for humid regions, and for regional estimates of infiltration and recharge in arid and semi-arid regions. Since that time, modeling of the land/atmosphere interface has significantly advanced, primarily due to the advance in computational power allowing more complex representations of the soil hydraulic behavior to be considered. It is now common for large-scale infiltration models to incorporate the highly non-linear Richards equation for water transport in soils, and more representative models of root water uptake and transpiration to help close the water budget at the land surface. These models still require significant field measurements of soil and plant parameters; however, we have also advanced quite a bit since 2005 in the area of field- and laboratory-based measurements of soil hydraulic properties, and shallow geophysical techniques to better quantify the subsurface soils and geologic heterogeneity.

As with fast pathways, the resolution of "whose model is right" remains an open question for the future of Yucca Mountain. The model used in the licensing application was criticized by internal and external review, yet it is now what the repository is based upon. The modeling may simulate the magnitude and distribution of infiltration consistent with reality, but it has been documented that it is not "right" in that its underlying data are highly uncertain or not available. The review issues raised lead to a lack of closure and confidence in the modeling effort that will only compound the future uncertainty and erode public confidence. As pointed out by Gelhar [32] the data "drought" cannot be made up with a modeling "deluge". Data will always be uncertain and scientists will always want more, but deluging with models actually compounds the uncertainty by covering over the data gaps with model results that are often "paper-thin" and can easily be peeled away by critics to show the underlying gaps. It can quickly lead to an "emperor with no clothes" where the public and regulators begin to look at all model results, independent of the scientific validity with skepticism and a polarized eye.

If Yucca Mountain is to move to a place of reduced uncertainty, modern infiltration modeling, using the recommendations of the various reviews of the MASSIF modeling, should be combined with a renewed field data campaign to fill in the low-hanging fruit such as soil depth. Without attempting to fill in some of these "holes", they will only get deeper and bigger, swallowing up truckloads of paperwork, lawyers and the public and leaving the nuclear waste in limbo, stored in cooling ponds or in dry storage at the reactor sites.

\subsection{The Underground Waterfall}

In most places beneath Yucca Mountain, the water table (the first occurrence of groundwater) is quite deep and indicates a flow direction toward Death Valley. However, just to the north of Yucca Mountain, the water table steeply dips, with a drop of almost $300 \mathrm{~m}$ in depth over a very short distance. The region termed the Large Hydraulic Gradient region [33], or LHG, has been the subject of considerable study and modeling [32,34]. In its early years, it was suggested that it was a perched water table [35] while now it appears to be considered part of the regional aquifer system. Yet, there remains no surface or inferred subsurface features that support a clear understanding of the cause of this steep drop in the hydraulic head of the volcanic aquifer underlying Yucca Mountain. Usually, such large 
drops in the water table indicate the presence of a fault or some type of barrier to flow. In the region of steep gradient, most of the fault structures tend N-S, which would tend not to restrict flow to the south.

The importance of the Large Hydraulic Gradient is twofold. In the first, its elevation is actually at or above the level of the proposed repository and there were early concerns of it flooding the repository [36]. Secondly, its presence may impact the saturated zone transport paths beneath Yucca Mountain. Zyvoloski et al. [34] conducted numerical simulations of the groundwater flow beneath Yucca Mountain using a variety of conceptual models for the source of the head drop, all of which focus generally on a reduction in permeability to the north due to hydrothermal alteration. Alternatively, the conceptual model for the Yucca Mountain license application (as implemented in the Total System Performance Assessment) assumes some form of east-west trending barrier feature through the LHG. Unfortunately, neither of these conceptual models have field-based evidence of their existence nor has there been significant energy expended in developing field data.

The Large Hydraulic Gradient is located hydrologically up the gradient of Yucca Mountain and its existence has the potential to impact flow directions and fluxes beneath and downstream of Yucca Mountain. Zyvoloski et al. [34] demonstrate numerically that flow paths can be sensitive to the nature of how the gradient zone is conceptualized. By incorporating both low permeability and enhanced fault flow, Zyvoloski et al. [34] were able to reproduce the results used in the license application and match reasonably well downstream hydraulic head measurements.

However, the fact that the anomalous groundwater behavior immediately to the north of the proposed repository is not understood nor has any evidence to support a solid conceptual model adds a significant amount of uncertainty to the general understanding of the groundwater beneath Yucca Mountain. In the early years of Yucca Mountain, the National Academy of Sciences, in reviewing the site conclude: "not until the source of the gradient (the $>300 \mathrm{~m}$ water table decline) is known can the potential hazard that the repository may face due to climate changes and/or tectonic events be evaluated with a high level of confidence" [33,36]. Its impact on the transport characteristics from Yucca Mountain may not be greatly significant, but it seems critical that major uncertainties, such as what makes the groundwater drop $\sim 300 \mathrm{~m}$ in $2 \mathrm{~km}$, be explainable and backed by field data. The lack of understanding, coupled with the apparent lack of interest in studying the phenomenon, challenges the belief by the public (and scientific) community that the site is sufficiently understood and explained to be appropriate for waste disposal. This is not a question of leaving no stone unturned, but rather a question that most reviewers of a peer-reviewed hydrogeology journal (or the National Academy of Science 30 years ago) would ask of a regional groundwater modeling paper. An explanation may not available yet, but suggestions and/or concepts on how to resolve or reduce the uncertainty would be appropriate.

\section{Conclusions and Looking Forward}

Our learning of the hydrology of arid regions began in the earliest of civilizations, with developments of qanats in Iran and irrigation along the Nile in Egypt. Yet, we continue to be surprised at the complexity and uncertainties in the processes governing water and solute transport in the subsurface. These uncertainties have not stopped humans from developing the water and soil resources of arid regions, however the search for safe and reliable waste disposal, including long-lived radionuclides, requires a level of certainty over long periods of time that has proven challenging. At each turn of characterization of Yucca Mountain, new processes and surprises were discovered, implying that we had underestimated the work needed to understand the system sufficiently to convince ourselves and the public that it would work as designed [12]. The examples discussed in this work highlight both the evolution of our knowledge, but also document the limited follow-up that was available to scientists to resolve the uncertainties with field data or further analysis. The singular focus on the Yucca Mountain site, driven often by political decisions, required that the site meet the regulatory measures of safety, with no opportunity to change course when, for example, it was discovered that rapid infiltration of surface water could reach the repository in less than 50 years, 
rather than the hoped-for 10,000 years. In addition, the short time for characterization has proven to be insufficient to resolve conflicting lines of evidence to a level that will be satisfactory to both local and national regulators.

Yucca Mountain has also shown that simply "following up" to reduce uncertainty may not be adequate to build a nuclear repository, as larger surprises or "show-stopping" processes may present themselves. For example, the realization that a fracture-dominated heat pipe cycle above the waste could cause corrosive fluids to "rain" down upon the canisters led, near the end of the site characterization phase, to the addition of titanium "drip shields" over each of the several thousand waste canisters. This untested and very costly engineering addition to the repository calls into question the entire concept of the need for a geologic repository. If such costly engineering is needed to ensure regulatory compliance, then perhaps it would be more logical to look to another, less complex site, yet this is not possible because Yucca Mountain was the only choice. Similar issues arise in the transport of waste to Yucca Mountain (or any repository); it will require the public to accept that large quantities of radioactive waste will be transported by rail or truck through communities and states. This will come as a surprise to many who have not followed or understood the concepts of a single national nuclear waste repository.

The uncertainties and challenges of characterizing a nuclear waste repository are not unique to the Yucca Mountain site, but the Yucca Mountain process does demonstrate the need for sufficient time for characterization. As clearly summarized by Rechard et al. [14], this is only one of several lessons learned from the US nuclear waste disposal characterization efforts over the past 50 years; flexibility in design, changes in how we classify nuclear waste, treating the storage and transport as an integral part of the disposal system and the understanding of public acceptance are also critical factors that need greater prioritization for the future of waste disposal. This review is not meant as a criticism of past work, but rather to demonstrate the importance of recognizing the complexity and the need to plan ahead for complexity, rather than simplicity. The issues raised in this work will require renewed scientific study and field data collection in order to provide closure to the questions, as well as to provide scientific and public confidence that the site is as best understood as it can be at this point in time. These results also point to the need for flexibility in the design and data collection of not only Yucca Mountain, but also any future disposal site.

Funding: This research received no external funding.

Acknowledgments: The author greatly appreciates the three anonymous reviewers who provided important and helpful comments/suggestions to improve the manuscript.

Conflicts of Interest: The author declares no conflict of interest. The author has been supported in the past (more than 15 years ago) by both the State of Nevada and the Department of Energy on the study hydrologic processes at both Yucca Mountain and the Nevada National Security Site.

\section{References}

1. Reith, C.C.; Thomson, B.M. (Eds.) Deserts as Dumps? The Disposal of Hazardous Materials in Arid Ecosystems; University of New Mexico Press: Albuquerque, NM, USA, 1992.

2. Gee, G.W.; Wierenga, P.J.; Andraski, B.J;; Young, M.H.; Fayer, M.J.; Rockhold, M.L. Variations in water balance and recharge potential at three western desert sites. Soil Sci. Soc. Am. J. 1994, 58, 63-71. [CrossRef]

3. Scanlon, B.R.; Keese, K.E.; Flint, A.L.; Flint, L.E.; Gaye, C.B.; Edmunds, W.M.; Simmers, I. Global synthesis of groundwater recharge in semiarid and arid regions. Hydrol. Process. 2006. [CrossRef]

4. National Academy of Sciences (NAS). The Disposal of Radioactive Waste on Land, Report of the Committee on Waste Disposal of the Division of Earth Sciences; National Research Council, National Academy of Sciences: Washington, DC, USA, 1957; Volume 519, p. 142.

5. Cotton, T.A. Nuclear Waste Story: Setting the stage. In Uncertainty Underground: Yucca Mountain and the Nation's High-Level Nuclear Waste; Macfarlane, A.M., Ewing, R.C., Eds.; The MIT Press: Cambridge, MA, USA, 2006; pp. 237-254. 
6. Stuckless, J.S.; Levich, R.A. The Road to Yucca Mountain-Evolution of Nuclear Waste Disposal in the United States. Environ. Eng. Geosci. 2016. [CrossRef]

7. Stuckless, J.S.; Levich, R.A. Characterizing the proposed geologic repository for high-level radioactive waste at Yucca Mt. Nevada-Hydrology and Geochemistry. In Hydrology and Geochemistry of Yucca Mountain and Vicinity, Southern Nevada and California; Stuckless, J.S., Ed.; Geological Society of America: Boulder, CO, USA, 2012; p. 393.

8. Hevesi, J.A.; Flint, A.L. Geostatistical Model for Estimating Precipitation and Recharge in the Yucca Mountain Region, Nevada-California; Water-Resources Investigations Report 96-4123; USGS: Reston, VA, USA, 1998. [CrossRef]

9. Applegate, D. The mountain matters. In Uncertainty Underground: Yucca Mountain and the Nation's High-Level Nuclear Waste; Macfarlane, A.M., Ewing, R.C., Eds.; The MIT Press: Cambridge, MA, USA, 2006; pp. $237-254$.

10. Montazer, P. Monitoring hydrologic conditions in the vadose zone in fractured rocks, Yucca Mountain, Nevada. In Flow and Transport through Unsaturated Fractured Rock-Geophysical Monograph; Evans, D.D., Nicholson, T.J., Eds.; American Geophysical Union: Washington, DC, USA, 1987; Volume 42.

11. Wang, J.S.Y.; Bodvarsson, G.S. Evolution of the unsaturated zone testing at Yucca Mountain. J. Contam. Hydrol. 2003, 62-63, 337-360. [CrossRef]

12. Macfarlane, A.M.; Ewing, R.C. Uncertainty Underground: Yucca Mountain and the Nation's High-Level Nuclear Waste; Macfarlane, A.M., Ewing, R.C., Eds.; The MIT Press: Cambridge, MA, USA, 2006.

13. Flint, A.L.; Flint, L.E.; Kwicklis, E.M.; Bodvarsson, G.S.; Fabryka-Martin, J.M. Hydrology of Yucca Mountain, Nevada. Rev. Geophys. 2001, 39, 447-470. [CrossRef]

14. Rechard, R.P.; Cotton, T.; Jenkins-Smith, H.C.; Nutt, M.; Carter, J.; Perry, F.; Weiner, R.F.; Blink, J.A. End of FY10 Report-Used Fuel Disposition Technical Bases and lessons Learned-Legal and Regulatory Framework for Implementation of High-Level Waste Disposition in the United States; SAND2010-6335; Sandia National Laboratory: Albuquerque, NM, USA, 2010; p. 182.

15. Montazer, P.; Wilson, W.E. Conceptual Hydrologic Model of Flow in the Unsaturated Zone, Yucca Mountain, Nevada. Water-Resources Investigations Report 84-4345; USGS: Lakewood, CO, USA, 1984.

16. Weeks, E.P.; Wilson, W.E. Preliminary Evaluation of Hydrologic Properties of Cores of Unsaturated Tuff, Test Well USW H-l, Yucca Mountain, Nevada; 84-4193; U.S. Geological Survey: Reston, VA, USA, 1984; p. 30.

17. Yang, I.C.; Rattray, G.W.; Yu, P. Interpretation of Chemical and Isotopic Data from Boreholes in the Unsaturated-Zone at Yucca Mountain, Nevada; 96-4058; U.S. Geological Survey: Reston, VA, USA, 1996.

18. Hinds, J.J.; Ge, S.; Fridrich, C.J. Numerical modeling of perched water under Yucca Mountain. Ground Water 1999, 37, 498-504. [CrossRef]

19. Flint, L.E.; Flint, A.L. Shallow Infiltration Processes at Yucca Mountain, Nevada-Neutron Probe Data 1984-93; 95-4035; U.S. Geological Survey: Reston, VA, USA, 1995; p. 46.

20. Flint, A.L.; Flint, L.E.; Bodvarsson, G.S.; Kwickless, E.M.; Fabryka-Martin, J.M. Evolution of the conceptual model of the unsaturated zone hydrology at Yucca Mountain. J. Hydrol. 2001, 247, 1-30. [CrossRef]

21. Stofhoff, S.A.; Walter, G.R. Average infiltration at Yucca Mountain over the next million years. Water Resour. Res. 2013. [CrossRef]

22. Nativ, R.; Adar, E.; Dahan, O.; Geyh, M. Water recharge and solute transport through the vadose zone of fractured chalk under desert conditions. Water Resour. Res. 1995, 31, 253-261. [CrossRef]

23. Stauffer, P.H.; Stone, W.J. Surface Water \Groundwater Connection at the Los. Alamos Canyon Weir Site: Part 2. Modeling of Tracer Test Results. Vadose Zone J. 2005. [CrossRef]

24. Fabryka-Martin, J.T.; Turin, H.R.; Brenner, D.; Dixon, P.R.; Liu, B.; Musgrave, J.; Wolfsberg, A.V. Summary Report of Chlorine-36 Studies as of August 1996. Report LA-13458-MS; Los Alamos National Laboratory: Los Alamos, NM, USA, 1998.

25. Cizdziel, J.; Smiecinski, A. Technical Report: Bomb-Pulse Chlorine-36 at the Proposed Yucca Mountain Repository Horizon: An Investigation of Previously Conflicting Results and Collection of New Data; TR-06-002, Rev.0 Prepared for the U.S.; Department of Energy: Washington, DC, USA, 2006.

26. Campbell, K.; Wolfsburg, A.; Fabryka-Martin, J.; Sweetkind, D. Chlorine-36 data at Yucca Mountain: Statistical tests of conceptual models for unsaturated-zone flow. J. Contam. Hydrol. 2003, 62-63, 43-61. [CrossRef]

27. Bodvarsson, G.S.; Kwicklis, E.M.; Shan, C.; Wu, Y.S. Estimation of percolation flux from borehole temperature data at Yucca Mountain, Nevada. J. Contam. Hydrol. 2003, 62-63, 3-22. [CrossRef] 
28. Technical Evaluation of the U.S. Department of Energy Yucca Mountain Infiltration Estimates: A Report to Congress and the Secretary of Energy (December 2007); Nuclear Waste Technical Review Board: Arlington, VA, USA, 2007; p. 22.

29. Independent Review of Simulation of Net Infiltration for Present-Day and Potential Future Climates. United States. Available online: https://inis.iaea.org/search/search.aspx?orig_q=RN:39107741 (accessed on 11 January 2020).

30. Simulation of Net Infiltration for Present-Day and Potential Future Climates. Available online: https: //inis.iaea.org/search/search.aspx?orig_q=RN:36090570 (accessed on 11 January 2020).

31. Simulation of Net Infiltration for Present-Day and Potential Future Climates, Revision 1; Addendum 1. Available online: https://www.nrc.gov/docs/ML0907/ML090770523.pdf (accessed on 13 January 2020).

32. Gelhar, L.W. Contaminant transport in the saturated zone at Yucca Mountain. In Uncertainty Underground: Yucca Mountain and the Nation's High-Level Nuclear Waste; Macfarlane, A.M., Ewing, R.C., Eds.; The MIT Press: Cambridge, MA, USA, 2006; pp. 237-254.

33. Fridrich, C.; Ge, S.; Sass, J. The Mechanisms of the Large Hydraulic Gradient under Yucca Mountain, Nevada; 98-119; US Geological Survey: Reston, VA, USA, 1998; p. 25.

34. Zyvoloski, G.; Kwickless, E.M.; Edebbarh, A.A.; Arnold, B.; Faunt, C.; Robinson, B.A. The site-scale saturated flow mode for Yucca Mountain: Calibration of different conceptual models and their impacts on flow paths. J. Contam. Hydrol. 2003, 62-63, 731-750. [CrossRef]

35. Saturated Zone Flow and Transport Expert Elicitation Project. Available online: https://digital.library.unt. edu/ark:/67531/metadc719833/ (accessed on 11 January 2020).

36. National Academy of Sciences (NAS). Ground Water at Yucca Mountain-How High Can It Rise; National Research Council, National Academy Press: Washington, DC, USA, 1992; p. 231.

(C) 2020 by the author. Licensee MDPI, Basel, Switzerland. This article is an open access article distributed under the terms and conditions of the Creative Commons Attribution (CC BY) license (http://creativecommons.org/licenses/by/4.0/). 